\title{
A cervicofaciális actinomycosisok jellemzői és korszerú diagnosztikája: összefoglaló az irodalmi adatok alapján
}

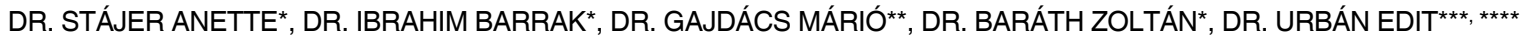

\begin{abstract}
Az Actinomyces nemzetség tagjai az ember normál mikrobióm alkotóelemeinek tekinthetők. Az Actinomyces spp. infekciókat ritka fertőzésekként tartják számon, anatómia lokalizáció alapján a cervicofaciális fertőzéseket tekintik a klinikai gyakorlatban a legelterjedtebb típusnak. Az actionomycosis klinikai képe összetéveszthető más kórképekkel, pl. szolid tumorokkal vagy más fertőző ágensek által indukált folyamatokkal. Ezeket a fertőzéseket lassan progrediáló (indolens) klinikai lefolyás jellemzi, nem-specifikus tünetekkel. Az actinomycosis klinikai diagnosztizálása kihívást jelenthet és számos mikrobiológiai és kórszövettani vizsgálati módszer akalmazását igényli. Jelen összefoglaló közlemény célja, hogy fogorvosok számára összefoglalja a cervicofaciális Actinomyces infekciók klinikai tulajdonságaival, diagnosztikájával és terápiájával kapcsolatos aktualitásokat .
\end{abstract}

Kulcsszavak: actinomycosis, cervicofacialis, terápia, diagnosztika, mikrobiológia

\section{Bevezetés}

Az actinomycosis olyan, ritkán előforduló endogén eredetű krónikus szuppuratív, granulomatózus infekció, melyet abscessus képződés, a sinus tractusok duzzanata, fistulák és szöveti fibrózis jellemez [2, 18]. Számos más állapotot utánozhat, különös tekintettel a rosszindulatú daganatokra és a granulomatusos megbetegedésekre, így a fej és a nyak bármely lágyrész duzzanatának differenciáldiagnosztikája során gondolni kell rá $[14,30]$. Az actinomycosis leggyakoribb anatómiai lokalizációja a cervicofaciális régió, ez az esetek $50 \%$-át teszi ki, míg a központi idegrendszer, a mellkas, a has és a medence actinomycosisa ritkábban fordul elő [1, 2]. Az actinomycosis kórokozói a humán és állati normál mikrobiom részét képezik: a kórokozók az Actinomyces nemzetségbe (melyre jellemző a genom magas guanin-citozin $\mathrm{G}+\mathrm{C}$ ) tartalom, 55-68\% az Actinomyces genus esetében), illetve az Actinomycetales rendbe tartozó Grampozitív, nem spórás, filamentózus anaerob és/vagy fakultatív anaerob baktériumok filogenetikailag heterogén csoportját alkotják [9, 20]. Néhány Actinomyces species régóta ismert a különböző humán és állati kórfolyamatokban, azonban az elmúlt években (köszönhetöen az új, egyre szélesebb körben elterjedt molekuláris diagnosztikai eljárásoknak) számos új, eddig nem ismert Actinomyces species és hozzá közel álló taxon (pl. Arcanobacterium és Actinotignum) került leírásra különböző patológiás folyamatokból [5-8, 10]. Jelenleg a szakirodalmi adatok alapján az Actinomyces nemzetségbe 49 faj tartozik, ezek közül eddig 26 fajt írtak már le bizonyítottan kórokozóként különböző humán fertőzésekben (Táblázat). Az esetek döntő többségében az Actinomyces israelii, de az A. meyeri, A. odontolyticus, $A$. viscosus, $A$. naeslundi is lehet kórokozója a betegségnek $[5-8,10]$. Újabban az $A$. neuiit, $A$. turicensist, és az $A$. bernardiaet is a potenciális humán odonto-patogének közé sorolják [5, 8-10, 17].

Az actinomycosis elnevezése egy összetett görög szóból származik: „aktino” sugarat jelent, ami a szövettani képen jellegzetes granulumok sugaras elrendeződésére utal, a „mykos” jelentése gomba, ami a betegség eredetét tévesen mutatja [22]. Ennek fordításából származik a helytelen magyar elnevezés is: sugárgomba-betegség, az actinomycosist azonban ma már egyértelmúen a bakteriális megbetegedések közé sorolják. Az actinomycesek jellegzetessége, hogy a gombákkal ellentétben kitin nem vesz részt a sejtfal felépítésében, ezzel szemben a muraminsav igen [28]. Antibakteriális kezelésre érzékenyek, antifungálisra azonban nem. Az actinomycesek a normál humán száj, bél és a női genitális mikrobiom tagjai, a szájüregi kolonizáció általános helyszínei a tonsillaris crypták, carieses léziók, a dentális biofilm, fogkő, az ínybarázda, sulcus gingivalis, illetve a nyál és nyálmirigyek [16, 17]. A fertőzés leggyakrabban a fogínyt, a torokmandulákat, a foggyökeret, az arc és nyak bőrét, a tüdőket, hasi és kismedencei szerveket érintheti, akár több szervet is, kombinálva. A be- 
Humán infekciókban igazolt patogén szerepben leírt Actinomyces fajok

\begin{tabular}{|c|c|c|c|}
\hline A. bovis & A. graevenitzii & A. nasicola & A. radingae \\
\hline A. cardiffiensis & A. hominis & A. neuii & A. timonensis \\
\hline A. dentalis & A. hongkongiensis & A. odontolyticus & A. turicensis \\
\hline A. europaeus & A. israelii & A. oris & A. urogenitalis \\
\hline A. funkei & A. massiliensis & A. oricola & A. viscous \\
\hline A. georgiae & A. meyeri & A. pyogenes & \multirow{2}{*}{$\begin{array}{l}\text { számos, még nem definiált } \\
\text { geno-species }\end{array}$} \\
\hline A. gerencseriae & A. naeslundii & A. radicidentis & \\
\hline
\end{tabular}

A félkövér betǔvel jelzett fajok okozzák a humán infekciók több mint 90\%-át. $A z A$. odontolyticus és az $A$. meyeri a cervicofaciális régióban a leggyakoribb, míg az A. gerencseriae és az $A$. israelii minden más anatómiai régióban jelentős.

tegség megjelenési formája az orális és cervicofaciális actinomycosison kívül lehet thoracalis, abdominalis, pelvicus, továbbá központi idegrendszeri [2, 3, 13, 19].

Az actinomycesek opportunista kórokozók, nem tekinthetők a gazdaszervezettel szimbiózisban élő baktériumoknak, mivel nincs meg a baktériumok és a gazdaszervezet közötti, a szimbiózist alapvetően jellemző kölcsönös jótékony hatás, azonban parazitáknak sem tekinthetők, mivel az esetek többségében nem okoznak kárt a gazdaszervezetnek [9]. Kontaminánsként is jelen lehetnek a klinikai mintákban, de bizonyítottan patogén szerepet is játszhatnak infekciózus eredetű kórfolyamatokban [5, 15, 22, 32]. Infekciót egészséges egyénekben ritkán okoznak, betegséget, tehát tüneteket, főleg legyengült immunrendszerű egyéneken (diabetes mellitus, malignus hematológiai megbetegedések, HIV fertőzöttség, szervtranszplantáció, égett betegek stb.), pyogen (gennyes) folyamatokban szenvedőkön okoz [30]. Újabban két, korábban nem infekciós eredetűnek vélt cervicofaciális patológiás folyamat esetén is összefüggésbe hozzák az actinomycesekkel: az állkapocs biszfoszfonát osteonecrosisát és az osteoradionecrosist [5, 19, 23]. Mindkét kórkép esetében az Actinomyces spp. törzseit tartalmazó biofilmet a nekrotikus csont léziókban detektálták, ahol feltehetően elősegítették a csontszövet további károsodását. Általában a betegségnek kevés szisztémás jele van, a betegség forrása mindig endogén fertőzés eredménye. Mivel ezek a baktériumok alacsony virulenciájúak, ahhoz, hogy betegséget okozzanak elengedhetetlenül szükséges a nyálkahártya integritásának sérülése, illetve az elhalt szöveti struktúrák jelenléte [11, 17, 25]. A nem megfelelő szájhigiéne,

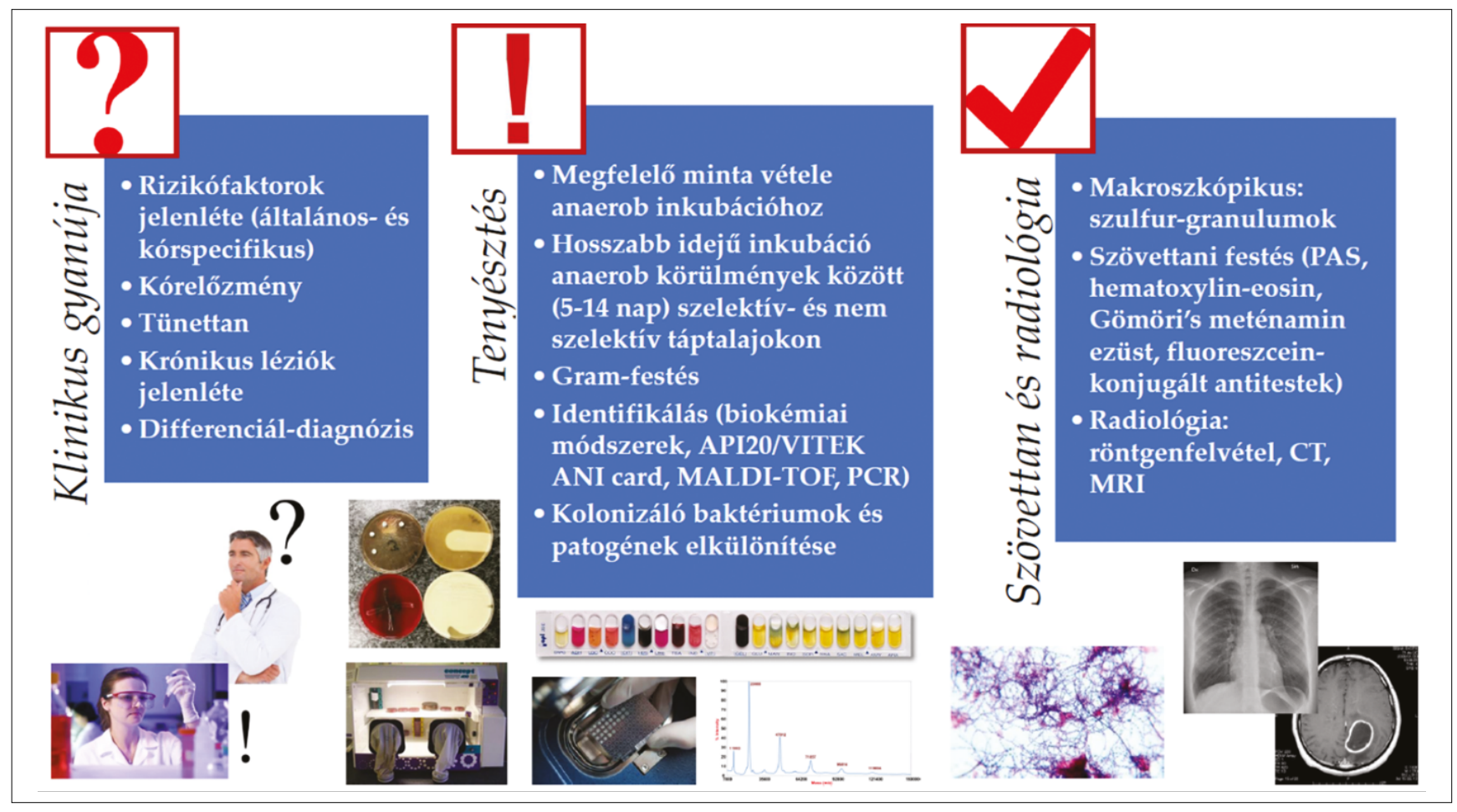

Az actinomycosisok diagnosztikai algoritmusának összefoglalása 
az elhanyagolt fogazat, a dohányzás és az alkoholizmus hozzájárul a betegség kialakulásához, illetve súlyosbíthatja azt. Az actinomycosis polimikrobiális fertőzés is lehet, amelyből általában több baktériumtörzs is izolálható, ugyanis a nyálkahártya sérülése nem az egyetlen oki tényező a betegség kialakulásában, a fertőzés kialakulásához gyakran egyéb, járulékos baktériumok, ún. ko-patogének jelenlétére is szükség van [16, 29]. Ilyen baktériumok lehetnek például Streptococcus spp., Eikenella corrodens, Aggregatibacter actinomycetemcomitans, illetve a Fusobacterium, Prevotella és Porphyromonas speciesek törzsei $[4,15]$. A ko-patogének gátolják a gazdaszervezet immunrendszerét, különböző toxinokat, enzimeket termelnek, lokálisan csökkentik az oxigén jelenlétét, megfelelő környezetet teremtve ezáltal az anaerob kórokozók társulásához a kórfolyamatban. Károsítják a környező jól vaszkularizált szöveteket, melyek granulációs szövettel pótlódnak, ezáltal szintén lehetővé teszik az anaerob környezet kialakulását, mely feltétele az actinomycesek szaporodásának: az actinomycesek alacsony invazivitása ezáltal számottevően megnő [24, 33]. Számos egyéb feltételnek kell teljesülnie az infekció kialakulásához, de a ko-patogének felelősek a fertőzés korai manifesztácójáért és gyakran a sikertelen kezelésekért is [9]. Kezdetben lokalizált gyulladásos szövetszaporulat, majd a betegség progrediálásával abscessus-szerű duzzanat kialakulása jellemző. Ez a szöveti határokat áttörve beszüri a környező szöveteket és előrehaladott formában számos fistulát képez, ezáltal közlekedhet a külvilággal. Ezekből izolálhatók azok a kénsárga granulumok (tőkék), amelyek jellegzetesek a kórképre, és melyek jelenléte megkönynyíti a helyes diagnózis felállítását [15, 20, 24, 30].

\section{Epidemiológia, klinikai prezentáció}

Az actinomycesek nem találhatók meg a környezetben, és a cervicofaciális betegséget okozó fajok számára az ember az egyetlen természetes rezervoár [27, 28]. Az antibiotikus éra előtt az actinomycosis gyakori megbetegedés volt, terápiájában csak sebészi módszereket alkalmaztak több-kevesebb sikerrel. Ha a gyógyulás jelei észlelhetők voltak is, gyakoriak voltak a szövődmények, és a halálos kimenetel sem volt ritka [9, 10]. Az antibiotikumok megjelenésével hatalmas fordulat következett be a betegek kezelésében.

Az első emberi actinomycosisról közölt publikáció 1857-ben jelent meg Lebert munkássága nyomán, bár a szarvasmarhákon jelentkező hasonló betegséget már azt megelőzően 30 évvel korábban is feljegyezték. Leblanc 1826-ban actinomycoticus duzzanatokat figyelt meg szarvasmarhákon, de tévesen osteosarcomának vélte azokat. Bollinger 1876-ban izolálta szarvasmarhából az $A$. bovist $[6,8]$. Szarvasmarha állkapocsból származó gennyes szövetmintát tanulmányozott, ennek során fedezte fel azokat a miceliumokat, melyeket a kórokozónak vélt. A szövetmintából a mikrobiológus
Harz szintén igazolta a sugárszerű organizmus létét, tőle származik a jól ismert $A$. bovis elnevezés. 1878ban Israel emberben is felfedezte a szarvasmarhában már kimutatott granulumokat, 1891-ben pedig humán cariesből izolálta a kórokozót [5-8, 10]. A szarvasmarhákban élő kórokozót 1890-ben Boestromnak sikerült kitenyésztenie. Elképzelése az volt, hogy a betegség exogén eredetü, mely a takarmányként használt széna elfogyasztása útján terjed. Bár nézete hibás volt, meglehetősen sokáig elfogadott maradt. Lord 1910ben végzett in vitro tanulmánya mutatott rá arra, hogy a humán actinomycosis endogén fertőzés eredménye. A kórokozót a tonsillaris cryptákból azonosította, melyet $A$. israeliinek nevezett el Israel úttörő munkásságának tiszteletére. 1940-ben került bizonyításra, hogy míg a szarvasmarhák megbetegedését az Acitnomyces bovis okozza, addig az emberi fertőzésért főleg az $A$. israelii a felelős [16]. Egészen az 1980-as évekig csak 6 humán patogén Actinomyces species volt ismert, azonban mára napról napra változhat az új, az irodalomban közölt speciesek száma [14, 15].

Az actinomycosis napjainkban viszonylag ritka előfordulású megbetegedés (bár egyes jelentések alapján éves előfordulása: 1/300000), azonban előfordulása valószínúleg nagymértékben aluldiagnosztizált, mivel sok laboratórium még mindig nem rendelkezik az anaerob baktériumok számára is megfelelő diagnosztikai (inkubációs körülmények: anaerobiózis, inkubációs idő, identifikációs módszerek, szakemberek) felkészültséggel [5, 19]. Az antibiotikumok használatával párhuzamosan a betegség incidenciája csökkent, a fatális kimenetel pedig ma már igen ritka. Az antibiotikumok mellett a preventív fogászati intézkedéseknek is nagy szerepük volt a betegség előfordulásának csökkentésében. Manapság az actinomycosisban megbetegedettek főleg a rossz szocio-ökonomikus státuszú, alultáplált, illetve rossz szájhigiéniájú betegcsoportokból kerülnek ki $[1,16]$. Az actinomycosis minden életkorban előfordulhat, de az esetek többsége a fiatal felnőtteket és a középkorúakat (20-60 év) érinti. Az irodalom szerint a betegség a férfi populációban fordul elő gyakrabban, a férfi-nő arány 3:1-hez [16, 18, 23, 24]. Az eddigi kutatások alapján csak közvetett bizonyítékot találtak arra, hogy a betegség miért érinti a férfiakat gyakrabban: főleg a környezeti tényezőkkel összefüggésben, míg fiziológiai, biokémiai és hormonális összefüggéseket nem találtak az érintett populációkban a két nem között. Mivel a maxillofaciális régióban keletkező traumák nemi megoszlása szinte azonos az actinomycosis nemi megoszlásával, feltételezhető, hogy a betegség férfiakon való gyakoribb előfordulása kapcsolatban van azzal, hogy a traumák elsősorban férfiakat érintenek [16]. A betegség kialakulásához szükséges a mucosalis barrier sérülése, amelyen keresztül az actinomycesek a mélyebb szövetekbe juthatnak, és ott megtelepedhetnek, így valószínűsíthető, hogy a betegség nemek közötti megoszlását mutató arányszám nem annyira a betegségre, mint inkább a traumák előfordulására vo- 
natkozik. A férfiak gyakrabban sérülnek a fej-nyak tájékon, mint a nők. A férfi predominanciát támasztja alá az a tény is, hogy szájhigiénéjük a női populációhoz mérve alacsonyabb [18, 20]. Az irodalmi adatok alapján a betegség a mandibulán sokkal gyakrabban jelentkezik, mint a maxillán (4:1) [16]. A betegség előfordulása raszszon belüli eltérést nem mutat $[18,23]$.

\section{A cervicofaciális actinomycosis klinikuma}

A cervicofaciális actinomycosis diagnózisának felállításakor számos probléma merülhet fel: a betegség klinikai képe több, különböző patológiás folyamathoz hasonlíthat, kezdve valamely jobb prognózisú fertőzéstől egészen a metasztatikus tumorokig [22, 26, 27, 29]. A definitív diagnózis felállítása mikrobiológiai és szövettani igazolással történik, azonban a pontos anamnézis felállításának is nagy jelentősége van. A fogorvos, szájsebész, fül orr gégész munkáját segítheti számos képalkotó eljárás is (UH, CT) [13, 31]. Az anamnézisben korábbi orofaciális trauma, szájsebészeti vagy fogászati beavatkozások is szerepelhetnek, az esetek többségében a betegek szájhigiénéje rossz. Krónikus tonsillitis, mastoiditis, otitis, sinusitis szintén fontos rizikófaktora lehet a betegségnek, ezért az anamnézis során ezeknek is nagy figyelmet kell szentelni [13, 31].

A betegség szinte kizárólag közvetlen invázióval, ritkán hematogén terjedéssel fordul elő. A cervicofaciális actinomycosis változó tünetekkel jelenik meg, de általában két különféle típus egyikében alakul ki: jellemző (a más anatómiai régiókban is előforduló Actinomyces fertőzések esetében is), a lassan elörehaladó (indolens) fertőzés, míg ritkábban a gyors és fulmináns lefolyás következhet be (különösen immunhiányos betegek esetén). Míg az indolens/krónikus forma kezdetben viszonylag fájdalommentes folyamat, az akut/fulmináns formában gyorsan súlyos fájdalom jelentkezhet [11]. A betegséget gyakran nem-specifikus lázas epizódok, köhögés és hirtelen súlyveszteség jellemzi, a laboratóriumi eredmények között figyelemfelkeltő lehet a fokozott leukocitózis, a fokozott erythrocyta süllyedés (erythrocyte sedimentation rate: ESR) és az emelkedett CRP (C-reactive protein: CRP) szint [2, 3, 9]. A betegségre jellemző, hogy nem okoz adenopathiát [16, 23], krónikus szövetszaporulat kialakulásával indul, amely gyakran trismushoz vezet, majd előrehaladott állapotban bőr-, illetve orális multiplex fistulák is megjelenhetnek. Ezekben a fertőzésekben krónikus, granulomatózus elváltozások alakulnak ki, amelyek az idő múlásával suppuratív jellegúvé válnak. Ezek a léziók általában több nagy tályogot (hideg tályogot) képeznek, amelyek sinus traktusokhoz kapcsolódhatnak, a sinusok tipikus, sürű sárga váladékot extretálnak, amely az Actinomyces spp.-re jellemző kéngranulumokat tartalmazza. Ezek a granulumok, amelyek először sárga színúek, de később sötétbarnává válnak, a filamentózus kórokozók tömegét tartalmazzák, és a kalciumsókkal biofilmet képeznek (fehérje-poliszacharid komplex) [5, 19, 27]. A léziót fedő bőr színe kékes-piros, a csomók a kezdeti stádiumban puha tapintatúak lehetnek, de a későbbi szakaszokban jellegzetesen kemény (deszkakemény) tapintatúvá válnak. A nyirokcsomók megnagyobbodása nem jellemző. A granulomatikus elváltozások átlépik a szövethatárokat, ezért előrehaladott állapotban (a rágáshoz használt izmok és az állkapocs beszűrődése, érintettsége miatt; az esetek 10\%-a), súlyos fájdalom, nehézségek a rágás során, trismus is előfordulhat [11, 31]. Súlyos, előrehaladott állapotban a fertőzés megtámadhatja az arckoponya csontjait és a betegség osteomyelitis kifejlődéséhez is vezethet. A legtöbb beteg esetében azonban az actinomycosis a submandibuláris vagy a perimandibuláris terület, a mandibulaszöglet, a parotis környéke, illetve a nyak akut gennyes gyulladásaként jelentkezik. A szájüregben a fertőzés akut abscessus, szubakut gyulladásos granuloma, felgyülemlett exudatum vagy pseudotumor képében jelentkezhet. Jellemzően az állkapocsszöglet környékén nodularis léziót fedezhetnek fel bimanuális vizsgálattal: a léziók száma és nagysága fokozatosan nő, többszörös abscessusok képződnek, és végül fistulaképződés figyelhető meg a buccalis vagy a submandibuláris régióban. A perimandibuláris régióból történő fistulaképződés a cervicofaciális actinomycosis legkönnyebben felismerhető megnyilvánulása [3, 8, 11].

Meg kell említeni, hogy periapicalis elváltozások, különösen a premolaris, illetve a molaris régióban szintén jó táptalajai lehetnek a fertőzés kialakulásának $[9,25$, 28]. Ha az orvosok szuppuratív elváltozásokat észlelnek a submandibuláris vagy perimandibuláris térségben, a sinus traktus, az állkapocs és a nyak mentén, az actinomycosis gyanújának fel kell merülnie, különösen a visszatérő fertőzések esetében [5, 21, 31]. Említésre méltó, hogy a (nem-specifikus) tünetek megjelenése és a klinikai diagnózis közötti időszak nagyon hosszú lehet (6-12 hónap), ami összhangban van az erózióval és a szöveti károsodás mértékével az érintett területen $[2,8]$.

\section{Diagnosztika}

\section{Szövettani vizsgálat}

Az actinomycosisok diagnosztikai algoritmusát az 1. kép foglalja össze. A citológia a legérzékenyebb módszer az egyes Actinomyces spp. által okozott infekciók diagnosztizálására [15, 26, 31]. A szövettani diagnózis javítása érdekében a különböző szövetszintektől származó több biopsziás minta vételét javasolják. A szövettani vizsgálat során, az actinomycoticus lézióból nyert mintákban az esetek 75\%-ában felfedezhetők azok a kénsárga granulumok, melyek a kórkép karakterisztikus jelei, jelenlétük azonban nem patognomikus az actinomycosisra, mivel számos baktérium termelhet hasonló granulumokat [2, 3, 19]. Ilyen például az Actinobacillus lignieresi, egyes Staphylococcus, Nocardia törzsek, de számos mycoticus fertőző ágens, mint a Sporotrichum 
vagy a Phialophore törzsek is. A granulumok kemények, daraszerűek és visszaverődő fényben sárga vagy fehér színűek, áteső fényben világos barnának és transzlucensnek tűnnek. Alakjuk kerektől az oválisig terjedhet. A granulumok tulajdonképpen izolált granulomatosus gyulladásos szövetszaporulatok, melyek centrumát suppuratív necrotikus szövet vagy sok mikroszkopikus suppuratív góc alkotja. Ezekben a necrotikus centrumokban találhatók a kénsárga tőkék, melyek küllőszerǔen rendeződött filamentumokból állnak. A gyulladásos reakció következtében emelkedett foszfatáz aktivitás miatt a granulumokat alkotó filamentumok mineralizálódnak. A filamentumok végei bunkószerűen kiszélesednek az ott rájuk tapadó neutrophil granulocyták és polymorphonucleocyták miatt. A granulumok mérete 100-300 ㅆm-től $2 \mathrm{~mm}$-ig változhat [2, 3]. A filmentumok közötti területet, illetve a centrális mag körüli részeket az Actinomyces baktériumok coccoid formái töltik ki. Különböző festési módszerek, például periodikus sav-Schiff-festés, hematoxilin-eozin-, Gömöri-methenamin ezüst-festés és fluoreszcein-konjugált specifikus antitestek (fluorescent-conjugated monoclonal antibody: FA) használhatók fel diagnosztikai célra [1, 9]. Hematoxylin-eozinnal festve a granulumok centrális része basofilan, míg a periférián található bunkószerű megvastagodások eosinofilan festődnek. A methenamin szürkével való festés is hasznos lehet, mert ez a festék különösen jól festi az öregebb filamentumokat. A speciális fungális festékek nem festik meg az actinomyceseket [16]. A perifériás granulomatosus szövetekben sok zsírsejt található, ami sárgás színét adja annak. A gyulladásos sejtek közül itt lymphocyták, plazmasejtek, epitheloid sejtek, histiocyták és alkalmanként óriássejtek találhatók meg. A kénsárga tőkékben három réteget különböztethetünk meg: a centrális necrotikus magot, melyben az actinomycoticus filamentumok is megtalálhatók, az ezt övező polymorphonuclearis neutrophilok rétegét és a külső fibrotikus réteget. Ennek a szklerotikus rétegnek köszönhetően a baktériumok szóródása gátolt, a nem megfelelő vaszkularizáltság viszont megakadályozza az antibiotikumok penetrációját, illetve fenntartja az anaerob körülményeket [16]. Ezzel magyarázható adott esetben a terápia sikertelensége vagy a betegség kiújulása is.

\section{Mikrobiológiai diagnózis}

Mivel az actinomycosis egyértelmú diagnózisát kizárólag a klinikai tünetek alapján nem tudjuk felállítani, ezért a végső diagnózis meghatározásához az infekcióért felelős mikroorganizmusok direkt vagy indirekt kimutatása szükséges. Az Actinomyces törzsek izolálása és azonosítása nagyon fontos lépés e betegség diagnosztikai eljárásában, azonban ezeknek a fertőzéseknek a laboratóriumi megerősítése gyakran nehéz [5, 24, 33]. A mikrobiológiai diagnosztika „gold standard”-ja a kórokozó tenyésztésén alapuló kimutatása. Az actinomycesek anaerob, vagy fakultatív anaerob baktériumok, általában érzékenyek az oxigén jelenlétére, így fontos, hogy a tenyésztéshez vett mintával miként járunk el.
A nem kellő körültekintéssel végzett mintavételi, mintakezelési eljárás hamis negatív eredményhez, rossz diagnózishoz, rossz terápiához vezethet, annak minden negatív következményével együtt. A mintákat ezért a mintavételt követően azonnal preredukált anaerob módon sterilezett (PRAS) transzport közegbe kell helyezni, majd minél hamarabb a mikrobiológiai laboratóriumba kell szállítani [8, 11]. Más anaerob kórokozókhoz hasonlóan az izoláláshoz nagyon fontos a mintavétel helye: a legjobb klinikai minták a szövetbiopsziás minták (az incisio mellett vékonytü aspiráció segítségével nyerhetünk mintát a tenyészethez), gennyek, fog-gyökércsatorna-váladékok, szublingvális plakk, aszeptikusan gyújtött csonttörmelék, ha osteomyelitis gyanúja áll fenn, míg a bőr- vagy nyálkahártya-tamponok, a köpet nem alkalmasak az azonosításra [30]. Polimikrobiális fertőzés gyanúja esetén az összes baktérium esetében meg kell kísérelni a tenyésztést és az azonosítást, hogy a jelenlévő releváns mikroorganizmusokat ki tudják mutatni, majd kombinált terápiát kell alkalmazni. A laboratóriumban meg kell teremteni az actinomycesek tenyésztéséhez megfelelő körülményeket. Mind dúsító tenyész-leves (agy-szív infúzió), mind nem szelektív és szelektív szilárd tápközeget (arginin-glicerin agar) kell használni az Actinomyces spp. sikeres izolálására [9], ehhez a sikeres izoláláshoz hét-tizennégy napig kell inkubálni a mintát a táptalajokon, szigorú anaerob körülmények között. Csont érintettsége esetén még hosszabb inkubáció ajánlott (21 nap), a baktériumok csökkentett szaporodási tulajdonságai miatt ebben a niche-ben $[9,10]$. $A z$ eredményeket befolyásolhatják a fertőzésért nem felelős, de a mintában jelenlévő, vagy a felszíneket kolonizáló más baktériumok, ezért egyes szakemberek a mélyebb szövetekből történő mintavétel mellett érvelnek, mert így minimalizálható az előbb említett ok. A kémcsövekben levő folyékony dúsító táptalajokban szabad szemmel is felfedezhetők a kénsárga granulumok, melyek a minták tárgylemezek közötti szétmorzsolása után is láthatók. A differenciál diagnózisban fontos a Gramfestés, mellyel egyértelműen láthatóak a tipikus alakok, a Nocardia fajoktól jól elkülöníthetők az Actinomyces törzsek, ezek az eljárások retrospektív vizsgálatokra is alkalmasak. Általában a kórfolyamatokért felelős Actinomyces törzseknek a nagy körültekintéssel végzett munka ellenére is csak mintegy $50 \%$-át tudják a mikrobiológus szakemberek hagyományos tenyésztéssel kimutatni. A sikertelenségnek több oka lehet: első helyen kell említeni a szoros szakmai együttmüködés hiányát a klinikus és a mikrobiológiai laboratóriumi szakember között, illetve az alkalmazott nem megfelelő mintavételi, vagy tenyésztési technikát, rövid inkubációs időt. A telepek mintegy 5 nap-két hét alatt fejlődnek ki, az ennél rövidebb inkubálási idő alatt a megfelelő típusos telepek még nem jelennek meg a szilárd táptalajok felületén, így hamis negatív tenyésztési eredményt kaphatunk [9]. Második okként kell említeni a mintában jelenlévő más baktériumok kompetitív hatását. Ezek egyszerüen túlnövik az actinomyceseket, elnyomják a kom- 
plex flóra tagjaként jelenlévő, lassabban fejlődő Actinomyces telepeket. Ilyen baktériumok lehetnek a Staphylococcus, a Streptococcus törzsek és különböző fakultatív és obligát anaerob Gram-negatív pálcák. A sikertelenség harmadik okaként pedig korábbi antibiotikus kezelést lehet megnevezni, ugyanis a szövetekben felhalmozódó antibiotikum megváltoztatja környezete oxido-redukciós potenciálját és így meggátolja az actinomycesek növekedését, illetve elpusztítja azokat, ezért a sikeres tenyésztés érdekében érdemes több mintát venni. Abban az esetben, ha ilyen technikával vett mintából nem lehet kitenyészteni az actinomyceseket, de a minta neutrophylokban gazdag volt, akkor azt is, mint az actinomycoticus fertőzés jelét kell számba venni [30].

A genusba sorolás nehézségei, egyes speciesek szokatlanul lassú növekedése valószínűsítik, hogy az actinomycesek által okozott infekciók előfordulása sokkal gyakoribb, mint a mikrobiológiai tenyésztéssel megerősített esetek száma [4]. Az izolálásuk után a baktérium speciesek identifikálása, genusba, majd species-szintű besorolása a következő fontos lépés. Jelenleg az Actinomyces genusba tartozó klinikai izolátumok speciesszintű meghatározása a fenotípusos jellemzőkön alapuló módszerekkel meglehetősen nehézkes, ami megakadályozza rokonsági fokuk megismerését, természetes tulajdonságaik, természetes lelőhelyük, pontos prevalencia adataik megismerését, és a patogenitásban betöltött szerepük felmérését [7]. A legtöbb problémát a módszerek rossz reprodukálhatósága, a törzsek biokémiai inaktivitása, lassú növekedése és a speciesek közötti közeli rokonság okozza. A szerológiának nincs jelentősége az actinomycosis diagnózisában [5, 9, 10, 21], míg az agglutininek és a komplement-kötő antitestek megjelennek néhány cervicofaciális actinomycosisban szenvedő beteg szérumában, keresztreaktív antitestek lehetnek jelen más betegségfolyamatok, különösen a tuberkulózis esetén.

Manapság egyre nagyobb tért hódítanak a mikrobiológiában a molekuláris diagnosztikai eljárások: úgymint a PCR módszerek, 16S rRNS gén szekvenálása, ARDRA módszer (Amplifikált Riboszomális DNS Analízis), DNSDNS hibridizáció, in situ fluoreszcencia hibridizáció [9], együtt a különböző molekuláris kémiai módszerekkel: (teljes-sejt fehérjeprofil meghatározás, riboszómális protein kimutatáson alapuló matrix assisted laser desorption ionization time-of-flight mass spectrometry: MALDI-TOF MS módszer stb.), melyek sokkal pontosabb speciesszintű meghatározást eredményeznek [3, 28]. Ezeknek az újonnan bevezetett módszereknek köszönhetően az elmúlt években számos új Actinomyces speciest és hozzájuk genetikailag közel álló taxonokat írtak le különböző humán és állati forrásból, kórfolyamatokból. Annak ellenére, hogy ma már 49 ismert species van, a sejtések alapján számos eddig még nem ismert species is felelős lehet mind humán-, mind állati-növényi kórfolyamatokért. Még pontosabb molekuláris vizsgálatok fognak pontos képet adni a korrekt species adatokról. Mivel a szájüregi normál flóra alkotói, ezzel fontos endogén infekcióforrások, így egyre több bizonyíték van arra, hogy számos új, eddig még nem ismert species játszik szerepet szájüregi infekciókban.

\section{Képalkotó eljárások}

Bár lehet, hogy nem járulnak mindig hozzá a pozitív diagnózis egyértelmű felálításához, a képalkotó technológiák hasznosak lehetnek az Actinomyces törzsek által kiváltott suppuratív léziók és a rosszindulatú daganatok differenciál-diagnosztikájában [3, 15]. Napjainkban a különböző klinikai képalkotó eljárásokat rutinszerüen alkalmazzák a pontos diagnózis felállításához a legtöbb betegség esetén. Cervicofaciális actinomycosis esetén a képalkotó eljárások hozzásegítenek, hogy meghatározzák a lézió pontos helyét és kiterjedését azért, hogy elkülönítsék a folyamatot a neoplazmatikus folyamatoktól, kiértékeljék az esetleges csontdestrukció mértékét, észlelni lehet a nyálmirigyek érintettségét, valamint követni lehet a betegség progresszióját, illetve válaszát az alkalmazott terápiára. A számos képalkotó eljárás közül használatos az orthopantomogram felvétel (OPT), computer tomographia (CT), sialographia, scintigraphia, illetve az ultrahang (UH) [11, 15], bár ezek az eljárások az actinomycosisra nem specifikusak [31], de intravénás kontrasztanyaggal kombinálva a lézió határai jobban láthatók. A lézió centrális része általában alacsony denzitású (hypodens) vagy sok alacsony denzitású részből áll össze, ezt az ott felszaporodott folyadék miatt lehet megfigyelni. A környező szövetekben a gyulladásos válasz következtében egy erősebb denzitású zóna látható. Gallium scintigraphia esetén a lézió intenzív nuklid felvételt mutat, ahol a centrális rész foton-deficiens része az abscessus vagy a tumor necroticus részét mutatja. A radioaktív nuklidokat alkalmazó képalkotó eljárások kitűnően alkalmazhatók a lézió vaszkularizáltságának megítélésére, így segítségükkel elkülöníthető, hogy gyulladásos vagy pedig tumoros eredetű az elváltozás. Ezek a diagnosztikai eljárások továbbá alkalmasak a betegség kórfolyamatának megbecsülésére, illetve a terápia hatására bekövetkező változások detektálására is. Nyálmirigy érintettség esetén jól használható a sialographia: az érintett nyálmirigyben a lézió helyén a kontrasztanyag felszaporodik, vagy szabálytalan lefutású üregeket rajzol ki, illetve kompressziós esetekben kontrasztanyag-hiányos foltok hívhatják fel az orvos figyelmét a betegségre. Actinomycotikus léziót ultrahanggal vizsgálva hyperechos foltokat detektálhatunk, ami a fibrosisnak és multiform abscessusoknak tulajdonítható [30]. Ez felhasználható az actinomycosis differenciál-diagnózisánál: a közönséges abscessusok ugyanis echomentesek vagy hypoechosak a felhalmozódott genny következtében. Fogászati panoráma röntgenfelvételek, a számítógépes tomográfia $(C T)$ és a mágneses rezonancia képalkotás (MRI) szintén értékesek a szövet érintettségének (hogy a csontszövet érintett-e) és a granulomatózus lézió lokalizációjának, méretének és méretének értékelésében [30, 31]. Azonban ma még leszögezhetjük, hogy önmagában egyetlen képalkotó eljárás sem képes az 
actinomycosis diagnosztizálására, ám más diagnosztikai eljárásokkal kombinálva nagyon hasznos lehet.

\section{Az actinomycosis kezelése}

\section{Sebészi kezelés}

Az antibiotikus terápia bevezetése előtt az actinomycosisban szenvedők meglehetősen rossz prognózisra számíthattak. 1938-ban a szulfonamidok terápiás alkalmazása jelentette az első sikert az actinomycosis kezelésében. 1948-ban Nichols és Herrell voltak az elsők, akik penicillinnel kezelték az actinomycosist. Azóta is a penicillin az elsőként választandó antibiotikum a betegség kezelésére. Az actinomycosisra jellemző, hogy a centrális nekrotikus régiót egy masszív fibrotikus zóna veszi körül [9]. Ez egy hipovaszkularizált szövet, alacsony oxidoredukciós potenciállal és alacsony penetrációs képességgel, így az antibiotikumok nagyon nehezen tudnak a lézióba bejutni. Az actinomycosis kezelésének ezért a nagy dózisú, hosszú ideig tartó antibiotikus terápia mellett magában kell foglalnia a sebészi terápiát is. Kisebb elváltozások esetén az antibiotikus kezelés mellett elegendő az incisio és a drainage biztosítása [16]. A lágyrészek mellett a nekrózis érintheti a csontszövetet is, mely esetben patológiás állcsonttörés következhet be [13]. Kiterjedt léziók esetén a környező szövetek alapos debrimentjét kell elvégezni a fistula falak eltávolításával. Egyes szerzők különféle öblítő oldatok (3\%-os hidrogén-peroxid) használatát is javasolják az anaerob környezet megszüntetése érdekében, illetve más, jódtartalmú bőr és nyálkahártya fertőtlenítő szerek is alkalmazhatók a terápia során: Braunol oldat, Betadin [1, 13]. A sinus maxillaris érintettsége estén Luc-Caldwell mútét, míg a sinus sphenoidalis involvációja esetén sphenoidectomia végzendő. A csontok fertőzöttsége esetén curettage és ablatios sequestratio szükséges, ugyanis az elhalt csont kitūnő táptalaj a baktériumok számára, így mint lehetséges fertőző forrást el kell távolítani [16].

\section{Antibiotikum terápia}

Előnyben részesített kezelési módok-általában hosszan tartó, nagy dózisú penicillint javasolnak az actinomycosis esetében [1-3, 9], az alternatívák közé tartozik a ceftriaxon és az amoxicillin használata. Az alkalmazás módja a fertőzés súlyosságától függ: a szövődmény nélküli cervicofaciális actinomycosis kezelését intravénásan adott penicillin G-vel kell elkezdeni, napi 3-12 millió nemzetközi egységgel (NE). Súlyos vagy kiterjedt actinomycosis-a súlyos, kiterjedt fertőzés gyakran invazív, purulens, vagy fistulákkal társuló folyamatokkal jár és gyakran jelentkezik súlyos komorbiditással járó betegekben, esetükben az intravénás penicillin G kezdeti beadását javasolják (napi 10-20 millió egység, négy-hat óránként osztott adagokban) [4-6]. A ceftriaxon (24 óránként 1-2 g) alternatíva, amelyet könnyebben be lehet adni a járóbeteg ellátás kezelésére [7, 26]. Penicillinrezisztencia az actinomycesek között még nem ala- kult ki. Sokkal gyakoribb, hogy a ko-patogének egyike válik rezisztenssé, s emiatt lesz hatástalan a kezelés. Ilyen esetekben olyan antibiotikummal kell kiegészíteni a kezelést, amelyre a rezisztens törzsek is érzékenyek. Az actinomycesekre hatástalan antibiotikumok a metronidazol, aminoglikozidok, cotrimoxazole, illetve a penicillináz-rezisztens penicillinek (methicillin, nafcillin, oxacillin, cloxacillin) $[7,26]$. Olyan szövődmények esetén, mint az actinomycoticus osteomyelitis, a beteg napi 12-20 millió nemzetközi egység Penicillin G-t kap négy egyenlő részben. Az intravénás kezelés 2-6 hétig tart, amit további 3-12 hónapig tartó penicillin készítmény per os adagolásának kell kövenie (Penicillin V) [16]. Penicillin-allergia esetén erythromycin, tetracyclin, clindamycin, első generációs cephalosporin, imipenem, lincomycin, doxycyclin adható [21, 31]. Terhesség esetén penicillint, illetve erytromycint kell választanunk. Az Amoxicillint önállóan is alkalmazhatjuk az actinomycosis enyhe, illetve közepesen súlyos eseteiben, mivel hatékony mind az Actinomyces, mind pedig a ko-patogén baktériumtörzsekre is. Felnőttek adagja $500 \mathrm{mg}$ per os 8 óránként vagy 875 mg 12 óránként. Gyermekek esetén $40 \mathrm{~kg}$ alatt $20-40 \mathrm{mg} / \mathrm{ttkg} / \mathrm{die}$ több részletben, míg $40 \mathrm{~kg}$ felett a felnőttek adagolását kell követni. Fokozott figyelmet igényel adagolása veseelégtelenség esetén, mert renális úton eliminálódik, így a dózist csökkentenünk kell, ha a kreatinin clearance $30 \mathrm{ml} / \mathrm{min}$ alá csökken. Bár a szisztémás gyógyszeres terápia hatásfokának javulása következményeként megkérdőjelezhető a sebészi terápia szükségessége, a hatékonysági vizsgálatok továbbra is a mútéti és gyógyszeres kezelés kombinációját javasolják [13, 26]. Az actinomycosis hónapokkal, évekkel a gyógyulás után is kiújulhat, ezért alapvető fontosságú a betegek időszakos visszarendelése és ismételt kivizsgálása.

\section{Összefoglalás}

Az actinomycosis napjainkban ritka előfordulású megbetegedés, halálos kimenetelű esetet évek óta nem regisztráltak Magyarországon. Egyrészt az antibiotikumok széleskörű alkalmazása, a jó szájhigiénét elősegítő intézkedések mind hozzájárultak a betegség incidenciájának csökkenéséhez, a klinikákon vizsgált és cervicofacialis actinomycosissal kezelt betegek, továbbá az irodalomban közölt esetek azonban valószínúleg csak a jéghegy csúcsát reprezentálják. Az immunhiányos betegek számának növekedése és a fogászati eljárások szélesebb körü elérhetősége miatt azonban ezen betegség gyakorisága növekszik. Az actinomycesek kimutatása a tenyésztések során egyértelmű bizonyítéka a megbetegedésnek. A negatív tenyésztési eredmény azonban nem feltétlenül jelenti az actinomycosis hiányát. Számos eset nem kerül mikrobiológiai laboratóriumi diagnosztizálásra a mintavétel és így a tenyésztés elmaradása miatt sem. Ezekben az esetekben a betegek gyógyulása kielégítő volt, ami nem tette 
szükségessé specifikus diagnosztikus eljárások elvégzését. Különösen a cervicofaciális actinomycosis esetén a klinikusoknak - az alapellátást végző orvosoktól a sebészekig -, a fogorvosoknak és a klinikai mikrobiológusoknak ismerniük kell ezt a megbetegedést, annak megelőzése (releváns kockázati tényezők jelenlétében), a megfelelő diagnózis és a kezelés érdekében. Az actinomycosis és az egyéb fertőző betegségek megkülönböztetése (tuberkulózis, nocardiosis, gombás fertőzések) a nem fertőző (daganatok) megbetegedésektől az első differenciál-diagnosztikai lépés és minden releváns diagnosztikai módszert alkalmazni kell. Mivel a hagyományos mikrobiológiai tenyésztési eredmények és a jellegzetes kénszemcsék jelenléte nem eléggé specifikus a végleges diagnózishoz, a beteg anamnesztikus adatait és jelenlegi fennálló tüneteit ismerni kell. $A$ betegek általában súlyos szövetkárosodással és súlyos tünetekkel rendelkeznek, a betegség lassú előrehaladása és indolens jellege miatt. Pozitív tény, azonban, hogy a betegség felismerése után az adekvát, megfelelően hosszú antibiotikum kezelésre adott válasz általában kielégítő, még azokban a betegekben is, akiknél már előfordult súlyos, kiterjedt nekrózis és szöveti károsodás.

\section{Irodalom}

1. Bhatawadekar S, Bhardwaj R: Actinomycotic bacteraemia after dental procedures. Indian J Med Microbiol 2002; 72-75.

2. Boyanova L, Kolarov R, Mateva L, Markovska R Mitov I: Actinomycosis: a frequently forgotten disease. Future Microbiol 2015; 613-628. https://doi.org/10.2217/fmb.14.130

3. Brook I: Actinomycosis: Diagnosis and management. S Med J 2008; 1019-1023. https://doi.org/10.1097/SMJ.0b013e3181864c1f

4. Collins MD, Hoyles L, Kalfas S, Sundquist G, Monsen T, NikolaitCHONK N, et al: Characterization of Actinomyces isolates from in fected root canals of teeth: description of Actinomyces radicidentis sp. nov. J Clin Microbiol 2000; 3399-3403. https://doi.org/ 10.1128/JCM.38.9.3399-3403.2000

5. Czirók É: Anaerob baktériumok. Klinikai és Járványügyi Bakteriológia, Melánia kiadó, 1999.; Budapest, Magyarország.

6. Funke G, Alvarez C, Pascual E, Falsen E, Akervall L, Sabbe L, et al: Actinomyces europaeus sp. nov., isolated from human clinical specimens. Int J Syst Bacteriol 1997; 687-692. https://doi.org/ 10.1099/00207713-47-3-687

7. Funke G, Pascual-Ramos C, Fernandez-Garayzabal J, Weiss N, ColuINS MD: Description of human-derived Centers for Disease Control coryneform group 2 bacterias Actinomyces bernardiae sp. nov. Int J Syst Bacteriol 1995; 57-60. https://doi.org/10.1099/ 00207713-45-1-57

8. Funke G, Stubbs S, von Gravenitz A, Collins MD: Assignment of human-derived cdc group 1 coryneform bacteria and cdc grop 1-like coryneform bacteria to the genus Actinomyces as Actinomyces neuii subsp. neui sp. nov., subsp. nov., and Actinomyces neuii subsp. anitratus subsp. nov., Int J Syst Bacteriol 1994; 167171. https://doi.org/10.1099/00207713-44-1-167

9. Gajdács M, Urbán E, Terhes G: Microbiological and Clinical Aspects of Cervicofacial Actinomyces Infections: An Overview. Dent $J$ 2019; e85. https://doi.org/10.3390/dj7030085

10. Hall V, Collins MD, Lawson PA, Falsen E, Duerden BI: Acinomyces dentalis sp. nov., from a human dental abscess. Int J Syst Evol Microbiol 2005; 427-431. https://doi.org/10.1099/ijs.0.63376-0

11. Hirschberg A, Tsesis I, Metzger Z, Kaplan I: Periapical actinomycosis: A clinicopathologic study. Oral Surg Oral Med Oral Pathol
Oral Radiol Endodont 2003; 614-620. https://doi.org/10.1067/ moe. 2003.87

12. INGLE JI: Death from Actinomycosis. J Endodont 2003; 685. https:// doi.org/10.1097/00004770-200310000-00019

13. Park JK, Lee HK, HA HK, Chol HY, Chol CG: Cervicofacial Actinomycosis: CT and MR findings in seven patients. Am J Neuroradiol 2003; 331-335.

14. Hsu JT, Lo HC, JAN YY, Chen HM: Actinomycosis mimicking recurrent carcinoma after Whipple's operation. World J Gastroenterol 2005; 1722-1724. https://doi.org/10.3748/wjg.v11.i11.1722

15. KoRITSÁNSZKY L, HAHN O: Cervicofacialis és pleuropulmonalis actinomycosis együttes elófordulása. Fogorv Szle 1997; 227-234.

16. Lawson PA, Akervall E, Vandamme P, Collins MD: Characterization of some Actinomyces-like isolates from human clinical specimens: reclassification of Actinomyces suis (Soltys and Spratling) as Actinobaculum suis comb. nov. and description of Actinobaculum schaalii sp. nov. Int J Syst Bacteriol 1997; 899-903. https:// doi.org/10.1099/00207713-47-3-899

17. Lawson PA, Nikolaitchouk N, Falsen E, Westling K, Collins MD: Actinomyces funkei sp. nov., isolated from human clinical specimens. Int J Syst Bacteriol 2001; 853-855. https://doi.org/10.1099/ 00207713-51-3-853

18. Miller M, Haddad AJ: Cevicofacial actinomycosis. Oral Surg Oral Med Oral Pathol Oral Radiol Endodont 1998; 496-508. https:// doi.org/10.1016/S1079-2104(98)90280-3

19. Nagler R, Peled M, Laufer D: Cervicofacial actinomycosis, a diagnostic challenge. Oral Surg Oral Med Oral Pathol Oral Radiol Endodont 1997; 652-656. https://doi.org/10.1016/S1079-2104(97) 90313-9

20. Nikolatchonk N, Hoyles El, Falsen J, Grainger M, Collins MD: Characterization of Actinomyces isolates from samples from human urogenital tract: description of Actinomyces urogenitalis sp. nov. Int J Syst Evol Microbiol 2000; 1649-1654. https://doi.org/ 10.1099/00207713-50-4-1649

21. Oostman O, Smego RA: Cervicofacial Actinomycosis: Diagnosis and Management. Curr Infect Dis Rep 2005; 170-174. https://doi.org/ 10.1007/s11908-005-0030-0

22. Orosz M, Ágh-Bíró Z, Osztheimer I, Pánczél P: Az actinomycosis cervicofacialis klinikai jellemzői és korszerű terápiája. Fogorv Szle 2007; 135-140.

23. Pascual C, Falsen E, Akervall E, B. Sjoden B, Collins MD: Actinomyces gravenitzii sp. nov., isolated from human clinical specimens. Int J Syst Bacteriol 1997; 885-888. https://doi.org/10.1099/ 00207713-47-3-885

24. Ricucci D. MD, DSS AND J. F. SIQUeIRA JR DDS, MSc, PHD: Apical actinomycosis as a continuum of intraradicular and extraradicular infection: case report and critical review on its involvement with treatment failure Nem elég ennyi adat!

25. Smego RA, Foglia G: Actinomycosis. Clin Infect Dis 1998; 1255. https://doi.org/10.1086/516337

26. Smith AJ, Hall V, Thakker B, Gemmell CG: Antimicrobial susceptibility testing of Actinomyces species with 12 antimicrobial agents. J Antimicrobial Chemother 2005; 407-409. https://doi.org/10.1093/ jac/dki206

27. Thukral R, Shrivastav K, Mathur V, Barodiya A, Shrivastav S: Actinomyces: A deceptive infection of oral cavity. J Korean Assoc Oral Maxillofac Surg 2017; 282-285. https://doi.org/10.5125/ jkaoms.2017.43.4.282

28. Tortorici S, Burruano F, Buzzanca ML, Difalco P, Cabibi D, MaRESI E: Cervico-Facial Actinomycosis: Epidemiological and clinical Comments. Am J Infect Dis 2008; 204-208. https://doi.org/10.3844/ ajidsp.2008.204.208

29. Tian X, Baumgartner JC: Occurence of Actinomyces in Infections of Endodontic Origin. J Endodont 2003; 549-552. https://doi.org/ 10.1097/00004770-200309000-00001

30. Varghese BT, Sebastian P, Ramachandran K, Pandey M: Actinomycosis of the parotid masquerading as malignant neoplasm. BMC Cancer 2004; e7. https://doi.org/10.1186/1471-2407-4-7

31. Venkatesh K, Saini ML, Niveditha SR: Fine needle aspiration 
cytology of cervicofacial actinomycosis. J Cytol 2008; 113-114. https://doi.org/10.4103/0970-9371.44050

32. Volante M, Contucci AM, Fantoni M, Ricci R, Galli J: Cervicofacial actinomycosis: still a difficult differential diagnosis. Acta Otorhinolaryngol Ital 2005; 116-119.
33. Wilst J, Stubbs S, Weis N, Funke G, Collins MD: Assignment of Actinomyces pyogenes-like (CDC coryneform group $\mathrm{E}$ ) bacteria to the genus Actinomyces as Actinomyces radingeae sp. nov. and Actinomyces turicensis sp. nov. Lett Appl Microbiol 1995; 76-81. https://doi.org/10.1111/j.1472-765X.1995.tb01290.x

Stájer A, Ibrahim B, Gajdács M, Baráth Z, Urbán $E$

\section{Advances in the diagnostics and therapy of cervicofacial actinomycoses: a literature summary}

Members of the Actinomyces genus are saprophytic components of the normal microbiota of humans. Actinomyces spp. infections are considered to be rare, with cervicofacial infections (frequently called as 'lumpy jaw syndrome') described as the most prevalent type in the clinical practice. Actinomycoses may resemble other pathologies, such as solid tumors or other infectious processes. These infections are characterized by a slowly progressing infection, with non-specific symptoms. The clinical diagnosis of actinomycosis may be difficult and it requires a plethora of clinical, microbiological and histopathological examination methods. The aim of this review is to summarize current advances on the clinical features, diagnostics and therapy of cervicofacial Actinomyces infections for dental specialists.

Keywords: actinomycosis, cervicofacial, therapy, diagnostics, microbiology

\section{A 2020. évben végzett fogorvostan-hallgatók doktorrá avatása}

\section{A Semmelweis Egyetem Szenátusa}

2020. július 24-én a Semmelweis Egyetem Nagyvárad téri Elméleti Tömb Dísztermében ünnepélyes doktorrá avató ülést tartott, amelyen az alábbi fogorvostan-hallgatókat avatták fogorvosdoktorrá:

Baboth Adelin, Baksa Szilvia, Balogh Katalin, Bánszki Laura Fanni, Bartha Botond, Benedikti Bence Áron, Bognár Virág, Bolya-Orosz Fanni, Borbély Dóra, Bosch Anna, Bukovszky Botond, Černák Áron, Csiki Hilda, Debreceni Fanni Aliz, Dovala Gréta, Enkhtaivan Sunderiya, Erdélyi Vivien Gisela, Farkas Vivien Ildikó, Finta Lilla, Gábeli Janka, Gábor Kincső, Gátos Miklós, Gerő Eszter Magdolna, Greff Lívia Alexandra, Hegedüs Tamás, Heródek Péter, Hesz Anna, Jakab Gerle, Kabankin-Lévai Zita, Káli Balázs, Keglevich Bernát, Kiss Nikoletta, Komáromi Adrián,
Komlós Nóra, Kormos Veronika, Kovács Ákos, Kovács Aliz Zita, Kovács Eszter Csenge, Kováts Domonkos Bence, Laczkovszki Gyöngyvér, Láng Orsolya Anna, Lipták Klaudia Margit, Lipták Laura Mária, Májer Adrien, Majtényi Balázs István, Makk Richárd Miklós, Módos Dominika, Nagy-Csoma Luca, Nagy Bianka, Nagy Mátyás Róbert, Nagy Miklós, Németh Anna, Nguyen Viet Huy,

Novák Viktória, Novothny Kamilla, Olasz Vivien, Papócsi Petra, Patthy Borbála, Petrik Fabrícia, Puskás Fanni Andrea, Schmalzl Judit, Sebestyén Nikolett, Selmeczi Áron, Svidró Eszter, Szabó József, Szabó Judit, Szalai Réka, Szekér Dóra Edina, Szirmai-Szabó Emese, Szitó Lilla, Szlamka Lilla, Tajti Péter, Tompa Noémi, Ujj Krisztina,

Varmuzsa Edvárd Márton, Vass Andrea Fanni, Veress Gabriella, Vida Lívia Edit, Vízhányó Gréta, Winkler Dóra Katalin, Zala Noémi Gertrúd, Zámodics Máté, Zsila Barbara 